\title{
The Business of Bribery: Globalization, Economic Liberalization, and the 'Problem' of Corruption
}

Margaret E. Beare

Osgoode Hall Law School of York University, mbeare@osgoode.yorku.ca

James Williams

Source Publication:

Crime, Law and Social Change. Volume 32, Number 2 (2000), p. 115-146.

Follow this and additional works at: https://digitalcommons.osgoode.yorku.ca/scholarly_works

Part of the International Law Commons, and the Law and Politics Commons

(c) $(1) \Theta(9$

This work is licensed under a Creative Commons Attribution-Noncommercial-No Derivative Works 4.0 License.

\section{Recommended Citation}

Beare, Margaret E., and James Williams. "The Business of Bribery: Globalization, Economic Liberalization, and the 'Problem' of Corruption." Crime, Law and Social Change 32.2 (2000): 115-146.

This Article is brought to you for free and open access by the Faculty Scholarship at Osgoode Digital Commons. It has been accepted for inclusion in Articles \& Book Chapters by an authorized administrator of Osgoode Digital Commons. 


\title{
The business of bribery: Globalization, economic liberalization, and the "problem" of corruption
}

\author{
JAMES W. WILLIAMS \& MARGARET E. BEARE \\ Department of Sociology, York University, Toronto, Ontario, Canada M3J IP3 \\ (email:jamwil@yorku.ca)
}

\begin{abstract}
This paper is intended as a critical response to the emerging consensus within both academic and policy literatures that we are currently facing an epidemic of corruption which threatens to undermine the stability of economic and political development on both a national and global scale, and which requires both immediate and wide-ranging policy interventions. Based on a review of the publications and policy statements of the leading anti-corruption crusaders - namely the OECD, the IMF, and the World Bank - it will be argued that the recent concern with corruption is attributable, not to any substantive increase in corrupt practices, but rather, to the re-framing of corruption in light of broader shifts and transformations within the global economy.
\end{abstract}

\section{Introduction}

While available evidence suggests that corruption is an enduring and relatively constant feature of world political systems, ${ }^{1}$ the past decade has been witness to a noticeable shift in the treatment of the phenomenon on both academic and policy fronts. Specifically, corruption has emerged within the context of international policy debates as a serious social problem requiring integrated anti-corruption efforts on a global scale. With this international attention, what has historically been defined as a domestic issue, and subsequently, a cost of doing business with a select group of developing nations, has re-emerged as a global political concern. This qualitative shift is captured by Glynn, Kobrin, and Naim (1997) who note that, "Campaigns against corruption are hardly new. But this decade is the first to witness the emergence of corruption as a truly global political issue eliciting a global political response

... The 1990s, we would predict, are unlikely to pass without the achievement of significant legal and institutional anti-corruption reforms" (Glynn, Kobrin 
and Naim, 1997: 7).

To a large extent, this prediction has been borne out in practice as a number of international economic and development organizations have responded to this perceived "crisis" of corruption through a myriad of research initiatives, policy statements, and legislative reforms. These include the following:

- Proposed legislative and policy reforms submitted by agencies such as the Organization for Economic Co-operation and Development (OECD), the World Trade Organization (WTO), the International Chamber of Commerce (ICC), and the Organization for American States (OAS). These have largely taken the form of anti-bribery conventions prohibiting the practice of bribery by member nations. The recently approved OECD Anti-Bribery Convention is perhaps one of the strongest statements of this position.

- Anti-corruption initiatives and stricter lending policies ${ }^{2}$ on the part of international banking organizations such as the World Bank and the International Monetary Fund (IMF). These have been articulated according to a common, and coordinated strategy to enhance organizational surveillance and governance over the disbursement of funds to client countries (World Bank, 1997d; IMF, 1997).

- The formation of non-governmental organizations such as Transparency International (TI) whose primary mandate is the development and implementation of anti-corruption strategies on a worldwide basis.

- An amassing of research evidence on the part of both academics and policy makers linking corruption to poor economic growth and low political stability to which democratization, liberalization, and privatization are offered as the preferred policy responses (Doig, 1998; Elliott, 1997; Glynn, Kobrin and Naim, 1997; Ades and Di Tella, 1996; Hariss-White and White, 1996; World Bank, 1997a; IMF, 1997). 
Despite variations in their mandates and strategies, these efforts have coalesced into a fairly unitary and cohesive discourse on corruption. This discourse consists of four dominant attributes:

1. a conviction that corruption has increased to epidemic levels, and that globalization has provided much of the impetus and opportunity for this growth;

2. a high degree of consensus as to the nature, type, and cause of the global "corruption crisis" with corruption defined almost exclusively in terms of bribery ${ }^{3}$ and attributed to non-democratic and highly centralized political and economic systems;

3. a preoccupation with the effects of corruption on foreign investment, and only a secondary focus on its impacts within developing countries; and

4. "outsider" and top-down policy responses, such as democratization, privatization, free market liberalization, and various forms of institutional and macroeconomic reform which tend to target the "demand" rather than "supply" side of the corruption equation.

Two crucial observations follow from this discourse and its underlying foundations. First, despite the appearance of an array of separate voices all reaching the same conclusion(s), closer inspection of the corruption "debate" reveals a clear overlapping of positions and interests. With most of the research on the topic being sponsored and conducted by members of the major economic and development agencies - i.e. the IMF, the World Bank, and the OECD - there has been a strong convergence between academic, public policy, and corporate perspectives. ${ }^{4}$ This has contributed to a singular and highly politicized account of corruption, its underlying causes, and the necessary policy responses.

Secondly, these positions and interests have been articulated according 
to a primarily economic discourse which attributes the deleterious effects of corruption on domestic economic growth and development to its status as a source of uncertainty in economic exchanges, and thus, a barrier and disincentive to foreign investment (Glynn, Kobrin and Naim, 1997; LeVine, 1989; Rodrick and Rauch, 1997; Elliott, 1997). Undoubtedly, much of this effect stems not only from the existence of corruption as a variable cost, ${ }^{5}$ but also from its association with non-democratic and non-competitive market structures which are indicative of both restrictions on foreign trade and investment, and a lack of transparency and accountability in financial transactions. What is of particular interest here are the implicit links between this status of corruption as a form of economic risk and uncertainty, and the more general international policy debates surrounding globalization. These debates feature the professed need for improvements to both the accessibility of global capital to foreign markets, and the stability and manageability of these markets as they become increasingly global, and thus, unpredictable in nature. The preeminence of economic liberalization and democratization as the preferred policy responses to corruption are particularly telling here given their consistency with the more general interests of foreign investors in greater market penetration and transparency.

The appreciation of this wider political and economic context is critical to understanding the perceived "crisis of corruption" as it suggests that the status of corruption as a social problem is founded upon general and profound anxieties concerning the nature, direction, and management of the emerging framework of economic globalization, rather than more narrow concerns with national economic development and political stability. The implication here is that the key change that has occurred over the past ten years is not the growth of overall levels of corruption or the severity of its effects on domestic 
economic growth as the anti-corruption crusaders claim, but rather, the reframing of corruption as a source of economic risk and uncertainty that must necessarily be problematized according to the objectives and interests of the global economy. Thus, the epidemic of corruption is more perceived than real, and this perception is conditioned by a broader set of economic and political interests. It is important to note that, in adopting such a position, this paper is not refuting the existence of corruption, nor its status as a problem deserving of concerted national and international attention; rather, its intention is to provide a context for both the recent emergence of corruption as an object of international concern, and the particular manner in which this "problem" has been defined. Thus, our objective is to provide a critical counterpoint to the corruption discourse that has dominated both policy and academic literatures to date.

These links between the discourse of corruption and the wider context of economic and political globalization will be articulated through three main sections. The first will consist of a general analysis of the international reaction to corruption, and its homogeneity with respect to the causes, effects, and policy implications of corrupt practices. The second section will contextualize this discourse by tracing its relationship to the wider framework of globalization. Specifically, it will be revealed that the very same organizations that have emerged as critical players in the anticorruption crusade are also key proponents of economic globalization in general, and the strategies of capital mobilization and market governance in particular. In drawing together these two, apparently distinct and disparate, discourses of corruption and economic globalization, the third section will reveal that corruption has emerged as a social problem to the extent that it constitutes a potential barrier to the effective implementation of these global economic strategies - this due to its status as a form of 
economic risk and uncertainty in a market driven by both predictability and unfettered access. The paper will then conclude with a brief reflection on the implications of this discussion for the nature of control and order within the emerging global system and, in particular, the growing involvement of non-state institutions and agencies in producing and perpetuating a social order based on an explicitly economic and actuarial logic.

\section{The international reaction to corruption}

When viewed from within the context of the studies, reports, and policy statements issued by the key players in global economic and political policy, including the Organization for Economic Development (OECD), the World Bank, the International Monetary Fund (IMF), the Organization of American States (OAS), and the International Chamber of Commerce (ICC), what is clear is the belief that general levels of corruption have increased dramatically in recent years and are continuing to rise. ${ }^{6}$ Two specific aspects of this growth have been identified as warranting particular concern. First, there is the growing concentration of corruption in developing countries with fragile or underdeveloped democratic institutions and capitalist market structures (Klitgaard, 1988). In this context, corruption is seen as a serious threat to the objectives of political and economic stability within a liberaldemocratic model (Klitgaard, 1988; Meny, 1996). A recent press release from the non-government organization Transparency International serves as a strong testimonial to this concern, “... the impact of bribery on peoples lives and on democracy is greatest in the poorest countries and those in transition to free market systems. Here the bribery is like a wrecking ball, destroying good government, a free press and an independent Judiciary. 
Not to mention the destruction of basic health and education services" (Transparency International, 1997: 3).

The second cause for concern is the contribution of globalization to the perceived seriousness of the corruption problem. Globalization, it is argued, has both increased the opportunities for corrupt practices and made detection more difficult due to the proliferation of electronic commerce and offshore financial centres (Elliott, 1997; Leiken, 1997; OECD, 1996). This link between the context of globalization and qualitative shifts in the nature and incidence of corruption is directly captured by an OECD policy report which states, "The expansion and globalization of the world economy have given the problem a fresh dimension. The deregulation of financial markets, the virtual elimination of exchange controls, the spread of new information technology and the development of ever more sophisticated systems of payment are making it increasingly complicated to detect and punish corrupt practices" (OECD, 1996: 9). A similar sentiment is shared by Leiken (1997) who notes that, “... a revolution in public opinion is transforming [the corruption] issue. The hardships of global competition have exhausted voters' patience with government excesses and misconduct" (Leiken, 1997: 55). Ultimately, these two dimensions of the corruption debate are highly instructive as they suggest that the emergence of corruption as a social problem is not merely a case of reported or perceived increases in the frequency of corrupt practices, but rather, that it is a product of a specific social and economic context - that of globalization - according to which previously acceptable practices have been re-defined as objects of international concern and attention. It is this context which is key to understanding the nature and significance of the discourse on corruption.

Underlying these general statements concerning its growth as a global 
issue, there are two specific effects of corruption which are seen to warrant its status as a serious social problem. The first is primarily economic in nature and relates to the deleterious effects of corrupt practices on economic growth and the efficient distribution of economic resources (Doig, 1998; Bray, 1998; Sutton, 1997; Almond and Syfert, 1997; Elliott, 1997; Rose-Ackerman, 1997; Mauro, 1997, 1998; Murphy, 1995; Klitgaard, 1988; World Bank, 1997a; World Bank, 1997b; Gray and Kaufmann, 1998; Kaufmann, 1997; OECD, 1996; IMF, 1997). Empirical evidence for this is provided by a number of studies which have found corruption to be negatively correlated with both investment and growth (World Bank, 1997b). ${ }^{7}$ This economic perspective is clearly assumed by a 1997 World Bank report which argues that,

Global concerns about corruption have intensified in recent years. There is increasing evidence that corruption undermines development. It also hampers the effectiveness with which domestic savings and external aid are used in many developing countries, and this in turn threatens to undermine grassroots support for foreign assistance. Corruption is of growing concern to donors, nongovernmental organizations, and citizens in developing and industrial countries alike. (World Bank, 1997a: 2)

This leads the authors of the report to conclude that, "The international community simply must deal with the cancer of corruption, because it is a major barrier to sustainable and equitable development" (World Bank, 1997a: 2).

The second deleterious effect involves the role of corruption in undermining the legitimacy of both local and national governments (Doig, 1998; Sutton, 1997; Rose-Ackerman, 1997; Murphy, 1995; Klitgaard, 1988; World Bank, 1997b; Gray and Kaufmann, 1998; OECD, 1996). According to a recent World Bank Report, "Corruption violates the 
public trust and corrodes social capital, and it can have far-reaching externalities. Unchecked, the creeping accumulation of seemingly minor infractions can slowly erode political legitimacy to the point where even honest officials and members of the public see little point in playing by the rules" (World Bank, 1997b: 2). This is seen to have serious implications for the political viability and stability of developing nations in particular. In combination, these effects of corruption on economic development and political legitimacy are deemed to be problematic to the extent that they undermine the principles of what has been termed "good governance,"

The damaging effect of corrupt practices on good governance is well known and applies to all countries. It subverts the governmental decisionmaking process, distorts development inducing inappropriate expenditures and waste of needed resources and undermines the legitimacy of governments. Whatever the economic and political situation of a country, the impact of corruption can be very serious. Policies of good governance which create a favourable environment for the corruption-free implementation of public policy need to be vigorously promoted.

(OECD, 1996: 5)

This international perspective on corruption and its effects is telling in a number of respects. First, the entire notion that corruption constitutes a threat to national economic development is couched in the assumption that foreign investment is essential to domestic growth. Thus, the central threat is not to the allocation of domestic resources, but to the effective, efficient, and accountable capitalization of foreign investment. Secondly, an explicit connection is made between national development, political stability, and the processes of democratization and liberalization. Here any domestic 
conception of development is overlooked in favour of policies which are manifestly Western in nature and design, and thus, feature the expansion of democratic political and economic structures as the key to prosperity within the developing world - not to mention the greater penetration of foreign investment into new markets. It is these very processes and institutional structures which are assumed by the term "good governance," and in relation to which corruption is defined as a serious economic and political threat.

The extent to which the international corruption discourse is embedded within the political and economic objectives of Western nations is even more clearly revealed in discussions of the proposed causes of corruption and their perceived implications for foreign policy. In terms of the former, corruption is largely attributed by OECD, World Bank, and IMF reports to the "overdevelopment" of the state in developing countries, and hence, the existence of monopolistic and non-competitive market conditions (World Bank, 1997a; World Bank, 1997b; Mauro, 1998; Gray and Kaufmann, 1998; OECD, 1996). When coupled with a lack of transparency in the political process, this socio-economic context is understood to create widespread opportunities for corruption through both the production of economic rents, and the establishment of institutional arrangements which provide government agents with a high degree of autonomy, and subsequently, an absence of accountability for their daily activities. The importance of economic rents for corruption is clearly stated by Mauro (1998) who argues that, "A key principle is that corruption can occur where rents exist - typically, as a result of government regulation - and public officials have discretion in allocating them. The classic example of a government restriction resulting in rents and rent-seeking behaviour is that of an import quota and the associated licenses that civil servants give to those 
entrepreneurs willing to pay bribes" (Mauro, 1998: 1). ${ }^{8}$ These factors, combined with the low pay accorded government officials in many developing nations, are believed to provide ideal conditions for corrupt practices through which political status is translated into economic wealth. For the most part, this etiology is re-iterated by the academic literature which similarly identifies the size of the state, the existence of non-competitive market conditions, and a lack of transparency and accountability in the political process as key factors in the onset and proliferation of corrupt practices (Goudie and Stasavage, 1998; Rose-Ackerman, 1997; Elliott, 1997; Ades and DiTella, 1996; Haniss-White and White, 1996).

In light of this understanding of the etiology of corruption, the most frequent solution proposed by both researchers and policy makers is the expansion of the processes of democratization and economic liberalization which, it is argued, will contribute to a reduction in the size of government, eliminate non-competitive market conditions, and introduce greater visibility and accountability into government practices (Elliott, 1997; Glynn, Kobri and Naim, 1997; Ades and Di Tella, 1996; Hariss-White and White, 1996; World Bank, 1997a; World Bank, 1997b; Gray and Kaufmann, 1998; Kaufmann, 1997; Leiken, 1997; OECD, 1996). Through the removal of conditions which generate opportunities and create value for corrupt practices, and which provide government officials with the autonomy and low visibility through which they may execute these exchanges, the presumed result will be a significant decrease in overall levels of corruption. This policy stance is most clearly articulated by Hariss-White and White (1996) who note that, "The policy implications of these analyses are that corruption can be reduced by rolling back the state through privatization and deregulation and by introducing more competition, transparency, and accountability into the political process through a 
transition to a democratic regime" (Hariss-White and White, 1996: 2). The implication here is that, "In the long run, since competitive constraints will destroy the basis of rent-seeking and democratic institutions will create the political constraints necessary to enforce accountability, corruption will wither away" (Hariss-White and White, 1996: 4). The importance of economic competitiveness is also a key element of the World Bank's anticorruption efforts, "Any reform that increases the competitiveness of the economy will reduce incentives for corrupt behaviour. Thus policies that lower controls on foreign trade, remove entry barriers to private industry, and privatize state firms in a way that ensures competition will all support the fight" (World Bank, 1997b: 3). Ultimately, it is a very specific, Western-based understanding of market discipline which underlies the bulk of the proposed reforms. This perspective is most clearly revealed in the comments of Robert Leiken (1997) on the benefits of privatization, "Privatization subjects erstwhile state resources to the discipline of the market and the oversight of investors. Exposing the public sector to internal, domestic, and international competition breaks up state monopolies. The freeing of exchange rates, the reduction of import and export tariffs, and the ending of price controls strip senior officials of the power to determine, for a 'fee,' the market price of many commodities" (Leiken, 1997: 68).

Overall, the policy reports issued by the major international aid and economic organizations all reiterate a series of widely agreed upon causes of corruption and its impending policy implications. Paulo Mauro, a researcher and policy analyst for the IMF, makes reference to this developing consensus, "We have a reasonable theoretical understanding of the causes and consequences of corruption, and have begun to get a sense of the extent of these relationships through empirical research. A consensus is 
emerging that corruption is a serious problem, and several bodies in the international arena have begun to take policy measures to curb it" (Mauro, 1998: 6). Within this framework, corruption is attributed to authoritative regimes who, through the size and breadth of the state apparatus, are able to create non-competitive economic and political markets which both generate economic rents, and provide government officials with a high degree of status, power, and autonomy. With corrupt practices linked to reductions in national economic efficiency, the destabilization of international trade and capital flows, and the undermining of the legitimacy of newly emergent democratic institutions, the proposed policy response typically includes broad policies of privatization, liberalization, and democratization to be complemented by more specific strategies such as increases in pay for government officials, the drafting of stricter legislative guidelines and administrative policies, and the general facilitation of greater transparency and accountability in government proceedings. These accounts of the causes, effects, and appropriate responses to corruption are strikingly consistent with the political objectives and foreign policies of Western nations, a link which provides a broader, and potentially more instructive, context from which the perceived "problem" of corruption may be viewed and contemplated.

At this point, based on the preceding review of both policy and academic literatures, we wish to highlight four weaknesses in the dominant international perspective on corruption. First, what is clear in many of these analyses is the disconnectedness of the concept of corruption from the social, political, and economic contexts and conditions of nation states and local communities. Disclaiming statements aside, "corruption" is most often treated within this discourse as a phenomenon which is uniform in nature and effect, and which may be understood independently of variations in 
national contexts and societal conditions. However, corruption is not only de-contextualized within these accounts, it is also defined in extremely narrow terms - most commonly as the acceptance of bribes and kickbacks by foreign government officials. Such a perspective is problematic to the extent that it neglects other forms of corrupt behaviour, belies the inherent variability in definitions of corruption (Johnston, 1996; Gibbons, 1989; Gardiner, 1993) across different nations and cultures, and systematically overlooks the complicit role played by international trading "partners" such as corporations who initiate bribes and international banks who facilitate the rapid flight of capital from less developed countries (Hampton, 1996).

A second weakness is the prevalence of an exclusively economic paradigm. This relates to the fact that, despite general and well-intentioned disclaimers as to the complex and manifold determinants and implications of corrupt practices, corruption is viewed by the international community in explicitly economic terms with little concern for its broader social and political implications. Furthermore, this economic framework is articulated in direct reference to the self-interested Western objectives of democratization and liberalization of world trade and investment. Within this context, corruption is largely viewed as a market distortion, and thus, a source of risk and uncertainty to foreign investors, rather than an obstacle to economic growth for developing nations. The predominance of this global economic perspective is made explicit within an OECD report in which it is stated that, "Recognizing that corruption is a many-faceted problem, we were well aware that by reviewing it solely from the standpoint of international trade we would touch upon only one of its dimensions" (OECD, 1996: 10). Any lingering uncertainties as to the economic pragmatism underlying the discourse of corruption are dispelled by Almond and Syfert's assertion that, 
"Ultimately, corruption will be contained because, quite simply, it is bad for business" (Almond and Syfert, 1997: 393).

A third concern warranted by the corruption discourse relates to its idealization of the "resisting forces" of corruption - i.e. privatization, liberalization, and democratization. In general, the policy literature is characterized by a naive and uncritical acceptance of these Western initiatives as the key solutions to the problem of corruption regardless of national circumstances and contexts. One of the key limitations of these policies, as they have been implemented in a variety of countries, is their narrowness and consequent inattention to the need for wide-ranging social and institutional reforms. This exact problem is noted by Kong (1996) who argues within the Korean context that the international trend towards liberalization and democratization has been largely ineffective in countering the institutional foundations of corruption in the country. For him, this reality stems from the narrow framework according to which these efforts are often conceived, "The evidence from countries where liberalization is advanced is that it is more a formula for promoting efficiency in a very narrow sense than a check against corruption. By contrast, fighting corruption demands effective regulation, the necessary conditions of which are the existence of a genuine countervailing institutional and societal power" (Kong, 1996: 55). Often, the result of liberalization and democratization under these circumstances is the facilitation of corruption. This has been observed by Tarkowski (1989) in Poland and the USSR, by Flannery (1998) in the African context, and by White (1996) in the case of China where he argues that, "Chinese market reforms have created an environment in which an official has greater freedom to abuse his or her position, has more motivation to do so and less motivation not to, and has many wellresourced people willing to join the transaction on terms which 
offer security as well as material advantage" (White, 1996: 45). What becomes clear from these case studies is the inadequacy of imposing principles of economic and political freedom in nature, while systematically neglecting the unique national characteristics and conditions which will determine their viability and reasonableness in practice.

The final concern precipitated by the corruption discourse is that while the policies advocated by the international community are extremely narrow in breadth, they are in fact very intrusive in terms of their depth. The international community is seemingly prepared to act with or without the cooperation or consensus of the countries targeted by anti-corruption policies. The invasiveness of this approach is reflected in the statement made by Kaufmann,

The time is ripe for a revolution ... The World Bank, which is poised to take concrete action can also deliver technical assistance programs to help reorganize customs institutions, develop transparent and effective treasury departments, and spearhead procurement and auditing reforms within governments ... Finally, international institutions should take steps to encourage participatory approaches in these countries in order to build consensus for anti-corruption drives and associated reforms. Civil society, wherever it is really present is likely to be a major ally in resisting corruption.

(Kaufmann, 1997: 130)

As revealed by this framing of the corruption problem, the participation of targeted countries represents a mere afterthought in anti-corruption initiatives. Once again, this is evidence of the oversimplification of the corruption issue as it is conceived within international debates, as well as the international community's inattention to local contexts and conditions as they relate to corrupt practices and behaviours. 
Overall, what emerges from this critical review of the policy and research literature on corruption is the consistency between the framework through which corruption has been defined, problematized, and remedied, and the broader interests and demands of the global market system. Thus, corruption is largely conceived of as an economic distortion which is believed to require wide-ranging and highly penetrating campaigns of democratization, privatization, and free market liberalization initiated almost exclusively by international organizations and agencies, and charted within a growing context of foreign aid and investment. Interestingly, the framing of the corruption problem in these terms not only identifies the expansion of the free market as a key anti-corruption strategy, but also requires and legitimates foreign intervention as the basis for the successful implementation of this policy. Clearly, this entire approach both mirrors and supports the reigning Western agenda for a free, and multi-lateral system of global trade and investment.

In light of this apparent homology, it is our belief that greater suspicion must be raised concerning the assumed status of corruption as a growing social problem. Supported by an absence of credible evidence that corruption has actually increased over the past decade, this more critical stance requires that we suspend this common assumption levied by researchers and policy makers and take a closer look at the broader social, political, and economic contexts and conditions within which the current discourse on corruption has been fashioned. Specifically, the context that must be critically examined is that of globalization as it is represented and defined by the same international agencies and organizations who have become major players in the corruption debate. The rationale for this approach is that it is only with the increasing globalization of capital and investment, and the corresponding demands 
for access, transparency, and predictability in financial transactions, that corruption has emerged as a critical social, political, and most importantly, economic issue. An initial sense of this primarily economic link between globalization and corruption is provided by Murphy (1995) who argues that,

... the globalization of trade as evidenced by the formation of the European Union, the signing of General Agreement on Trade and Tariffs (GATT), and, more recently, the ratification of North American Free Trade Agreement (NAFTA), makes the problem of bribery more urgent today than ever before.

(Murphy, 1995: 388).

Ultimately, what this perspective requires is a return to the anti-corruption crusaders - the OECD, the World Bank, and the IMF - and an analysis of their broader social, political, and economic mandates as they have evolved within the context of economic globalization. It is hoped that such an effort will help to lay bare the underlying nature and dynamics of the global discourse on corruption.

\section{Globalization and the world economy}

According to recent policy statements issued by the key players in the international arena - the OECD, the IMF, and the World Bank - we are currently in the midst of a series of fundamental and profound changes to the world economy. Specifically, it is argued that the forces of globalization, the transformation of political regimes, and the subsequent dismantling of pre-existing social and economic barriers, have precipitated a movement towards the globalization of investment, capital, and trade, and thus, the integration of the world's economies on a previously unprecedented scale. ${ }^{9}$ 
The profundity of these social, political, and economic changes is clearly articulated by Meny (1996) who notes that,

The doctrine of the market has been endorsed by the economic achievements of Japan and the new Asian tigers, and reinforced, conversely, by the collapse of the socialist countries and the growing difficulties of the social democratic governments in coping with their costly Keynesianbased policies. Everywhere, under the impetus of neo-liberals or under the iron rod of the World Bank, or even of OECD, vigorous policies of deregulation and privatization have dismantled the state's legal, economic, and financial control. Everywhere, new rules of the game have been imposed and new players have emerged. Old self-interested coalitions have been challenged under the impact of new ideas and increasingly pressing external constraints bound up with the formation of new regional blocs and the liberalization of world trade. (Meny, 1996: 315) ${ }^{10}$

From the perspective of researchers and policy analysts, this concurrent movement towards the mobilization of global capital and the progressive integration of national economics is understood to require a fundamental shift in the ways in which the economies of the world are managed (OECD, 1997). Specifically, it is argued that future economic growth and prosperity are dependent upon the establishment of a rules-based multilateral system according to which global capital is permitted to flow freely across international boarders on the basis of universally binding rules and legislative policies. Such a model is said to be necessary in order to both ensure the growing access of capital to foreign markets, and establish a normative framework of universally agreed upon rules, policies, and procedures according to which these capital flows may be governed. The intended result is not only the expansion of current levels of economic integration, 
but also the insurance that this integration will be executed under conditions of stability and predictability - key components of the market economy. According to the OECD, IMF, and World Bank, two specific and fundamental conditions must be met if such a global economy is to emerge: economic liberalization, and the establishment of a system of global economic governance.

The first objective, that of economic liberalization, is based on the principle that future global economic development is dependent upon the unfettered access of foreign capital to domestic markets. The typical rationale for this is that these liberalized economic regimes will generate new opportunities for foreign investment, ${ }^{11}$ and thus, attract significant capital flows to developing nations where it may be used to finance social and economic development. Typically, this scenario is seen to require a number of fundamental reforms to social, political and economic institutions - particularly within the context of developing nations - which are designed to reduce barriers to trade and investment, and to enhance the productive capacities of nation states. The pursuit of these policies is seen to be integral to the successful integration of national economies into the global market system,

Though the speed and sequencing of liberalization will have to be determined by each country in light of its particular circumstances, policies should be geared to the ultimate objective of full integration into the global financial system. To this end, countries will need to set in place forward-looking programmes for the removal of capital controls, the liberalization of cross-border financial services and the abolition of restrictions to market access by foreign investors and institutions. 
According to the OECD, the accomplishment of such transformations on an international scale is essential to the maximization of economic growth and prosperity for both developed and developing nations. This is referred to as the 'high performance scenario,' "The high performance scenario is not a forecast. It is a realistic possibility for the world economy, if governments undertake a wide range of necessary policy reforms. These include moving towards global free trade and capital movements, fiscal consolidation, structural reform and in the case of a large number of nonOECD economies developing the necessary capacity for development" (OECD, 1997: 7). The dangers of not fulfilling these strategic requirements are also made equally clear, "Against that, much worse scenarios could be envisaged, particularly if governments do not proceed with reform or do not resist protectionist pressures. A reversal of globalization could lead down the road of global fragmentation, with adverse effects for prosperity and political stability" (OECD, 1997: 8).

The corollary of this process of liberalization is the establishment of an effective system of economic governance through which emerging market economies may be integrated into the global economic order. The need for such a scheme stems from the reality that with rapid economic liberalization has come the emergence of a number of new market economies which are now open to global capital flows, and yet which lack the institutional and regulatory frameworks through which these trade and investment flows may be regulated. This dilemma is noted by Jomo (1998) who argues that, “... financial liberalization has undermined previously existing governance institutions and mechanisms without creating adequate alternatives in their place" (Jomo, 1998: 21). The absence of such an economic and political infrastructure is problematic to the extent that it allows these economies 
to operate independently of the principles and discipline of the market system, hence elevating their levels of systemic risk and threatening investor confidence. ${ }^{12}$ Within the context of ever increasing levels of economic integration, this situation makes both developing nations, and thus the world economy as a whole, much more susceptible to fiscal shocks and instabilities due to the constant threat of capital flight. ${ }^{13}$

In response to these concerns, organizations such as the OECD, the World Bank, and the IMF have become increasingly involved in the design and implementation of a system of economic governance whose primary mandate is the introduction of greater stability and predictability into the international economic system, and thus, the minimization of the risk and uncertainty invariably faced by global capital as it enters into foreign economies currently outside of the established market system. This general strategy consists of two key elements. The first is the establishment of stable and sustainable macroeconomic policies and positions. The necessity of these types of reforms, which typically include low inflation rates, a strong and sustainable fiscal position, the absence of large domestic price distortions, and a sound banking system, is clearly stated in a recent OECD policy report,

It is quite clear that stable and sustainable macroeconomic policy is a precondition for taking advantage of the opportunities provided by globalization, as well as for successful structural reform. This is particularly true for non-Member countries with a history of macroeconomic instability. Low inflation rates and sustainable fiscal positions reduce the riskiness and improve the allocation of savings and investment, thereby stimulating economic development. They also allow economies to take advantage of the opportunities offered by global financial markets.

(OECD, 1997: 23) 
While it appears from this account that developing nations are the primary beneficiaries of these reforms, in reality it is the interests of foreign investors which are driving the process of macro-economic re-structuring. This more realistic position is captured in a World Bank report which argues that,

... [developing nations] must implement policy reforms and strengthen institutions to make their markets more attractive to foreign investors and reduce the risks of capital market instability. While investors are attracted by the potential for rapid growth and high returns, they are discouraged by operating inefficiencies, by the lack of reliability of mar-

ket institutions and infrastructure, and by regulatory frameworks that increase transaction costs and reduce transparency. Improvements that increase the attractiveness of emerging markets for foreign investors also serve to reduce volatility and risks.

(World Bank, 1997d: 55)

Thus, the insurance of a stable and predictable investment environment figures prominently in the attempts to manage emerging markets.

The second key component of this loose framework of economic governance is the enactment of institutional reforms designed to introduce greater transparency and accountability into political and economic institutions. A core mandate of the OECD (OECD, 1997), the IMF (IMF, 1997; 1998), and the World Bank (World Bank, 1997d), this transparency is believed to be essential to a stable global economy as it provides a critical flow of information through which levels of economic risk may be ascertained, and thus, accurate investment decisions ultimately rendered. The establishment of an effective system of disclosure also constitutes an important source of accountability through which 
emerging economies are inevitably subjected to the discipline of the global market. The result is the reduction of systemic risk, the augmentation of investor confidence, and thus, the insurance of greater economic development and stability. Thus, it is argued within a recent World Bank report that,

Constructing and reinforcing the regulatory framework is essential for emerging markets to attract foreign investors and reduce systemic risk. Investors are most concerned with protection of property rights (including minority shareholder rights) and transparency. For example, investors want both macro data on economic prospects and micro data on corporate performance, to be able to make informed investment choices. Improving disclosure will not only address investor concerns but will also reduce the susceptibility of the market to volatility resulting from incomplete or asymmetric information.

(World Bank, 1997d: 57)

The establishment of a regulatory system premised upon the principles of transparency, disclosure, and market discipline is also featured in the recent policy work of the OECD. However, the emphasis here is placed more directly on the private sector and its responsibility for what is termed effective corporate governance,

If countries are to reap the full benefits of the global capital market, and if they are to attract long-term "patient" capital, corporate governance arrangements must be credible and well understood across borders. Adherence to good corporate governance practices will help reinforce the confidence of investors, may reduce the cost of capital, and ultimately induce more stable capital flows. $\quad$ (OECD, 1999: 2) 
Once again, it is the provision of information through clear disclosure practices which is identified as a key element of this strategy, "The corporate governance framework should ensure that timely and accurate information is disclosed on all material matters regarding the financial situation, performance, ownership, and governance of the company" (OECD, 1999: 7).

Overall, what emerges from this review of OECD, IMF, and World Bank policy statements is a clear drive towards the establishment of a global economic order premised upon high levels of economic integration, and thus, growth and prosperity. The pursuit of this global order is understood to entail two fundamental principles: access and accountability. Thus, we have an endless number of policy reports issued by each of these organizations detailing not only the benefits of the liberalization of trade and investment, but also the establishment of a framework of economic governance through which these liberated trade and investment flows may be governed in conjunction with the demands of the global capitalist economy. The establishment of clear disclosure practices and transparent regulatory frameworks figures prominently in these efforts. Perhaps the best expression of this dual strategy is the OECD's recent pursuit of a multilateral agreement on trade and investment (MAI) whose mandate is both the liberalization of trade and investment, and the establishment of a rulesbased multi-lateral system which will provide universal guidelines and protections for financial transactions. The importance of such a strategy is clearly articulated within an OECD policy report which states that,

Widely-accepted and effective international agreements on trade, investment, finance and taxation are essential supports for the multilateral economic system. Internationally-agreed rules of the game limit the scope for domestic regulations to distort transactions. 
Moreover, without such rules, there is a risk that countries might have recourse to "selective reciprocity" or opportunistically deviate from internationally-agreed upon principles for short-term advantage through, for example, trade and in vestment-distorting subsidies, arbitrary treatment of foreign investors, tax competition between governments, degradation in labour and environmental standards, bribery and corruption in international trade and, more fundamentally, swings between protection and liberalization.

(OECD, 1997: 23)

Ultimately then, it is clear that the international business community is currently invested in an effort to both expand the reach of Western nations into developing economies based on the promise of higher investment returns and diversified portfolios, and to minimize the systemic risks faced by these capital flows as they enter foreign markets which have embraced the logic of the capitalist system while failing to institute the required institutional and macroeconomic reforms to ensure a stable investment environment. This framework of global economic relations is highly instructive as it provides a fundamental context through which the corruption epidemic must be viewed.

\section{Globalization and the risks of corruption}

In juxtaposing the discourse of corruption with that of economic globalization it soon becomes clear that the recent transformations in the definition of the corruption problem are linked to the perceived shifts in the organization of the global economy. When viewed in these terms, it may be argued that corruption is problematic to the extent that it represents a source of economic risk and uncertainty to foreign investment, and thus, 
stands in contradiction to the market requirements of stability, security, and predictability. It is this very concern which is expressed in a 1996 OECD Working Report in which it is stated that,

[Corrupt practices] hamper the development of international trade by distorting competition, raising transaction costs, compromising the operation of free and open markets, and distorting the allocation of resources at the internal level. Corruption is a disincentive to investment: investors shun countries where it is endemic. Finally, corrupt practices in connection with development assistance cast discredit on the efforts being made, and provide justification for drastic cuts in aid budgets in donor countries.

(OECD, 1996: 9)

Similar views have been expressed in both the general policy and academic literatures where corruption has been identified at various points as a source of potential risk and uncertainty to the free flow of international capital (Goudie and Stasavage, 1998; Zedalis, 1998; Almond and Syfert, 1997; Glynn, Kobrin and Naim, 1997; Rodrick and Rauch, 1997; Elliott, 1997; Sutton, 1997; Randall, 1997; Murphy, 1995; LeVine, 1989; Rosenthal, 1989). This is what Goudie and Stasavage (1998) term the disincentive effects of corruption. "In addition to the distortionary impact that reduces the efficiency of present economic activity, the prevalence of corruption arguably acts on the economic environment in a far more insidious manner through the creation of significantly higher levels of risk and uncertainty in economic transactions" (Goudie and Stasavage, 1998: 143). It is based on this status as a source of risk and uncertainty that corruption is identified as a threat to the stability and integrity of the emerging world economy. This very insight leads Glynn, Kobrin and Naim (1997) to assert that, "As a growing number of experts are beginning to recognize, widespread corruption threatens the very basis of an open, multilateral world 
economy" (Glynn, Kobrin and Naim, 1997: 13), a danger that is strongly reiterated by LeVine who as early as 1989 recognized that, “... the new transnational corruption, once revealed, had to be recognized for what it was - a new and dangerous challenge to the stability and predictability of the international market"? (LeVine, 1989; 687).

Thus, while presenting national development and social equality as the key issues in the corruption debate, it quickly becomes apparent that these concerns belie a more fundamental and emergent awareness of corruption, particularly in the form of bribery and rent extraction, as a significant barrier to the efforts of Western nations to establish a free and efficient global economic system. Once again, the welfare of developing nations appears as an afterthought to the welfare and demands of international investors.

Despite the general recognition that corruption represents a barrier to trade and a source of risk and uncertainty to international investment, and that this risk has become amplified within the context of globalization, there has been little effort within the research literature to systematically examine these effects and their relation to more general developments within the global economy. Based on the preceding review of the policies of the OECD, IMF, and World Bank, it can be argued that this general status of corruption as a source of risk actually embodies three specific elements which undermine or threaten the objectives of economic globalization. The first is most consistent with the dominant view of corruption and relates to the status of corrupt practices as additional and variable costs within financial transactions. This is what Sutton (1997) refers to as a transactional barrier, "Transactional barriers play a harmful role in the international market, imposing additional costs on market actors and discouraging transactions from occurring. By forcing producers and consumers to pay higher costs in order to engage in the transaction, corruption functions as a transactional barrier. As such, 
corruption imposes additional costs on market actors with the effect of deterring market exchanges from ever taking place" (Sutton, 1997: 1438). It is important to note that this status of corruption as a transactional barrier consists not only of the elevated costs of investments, but also the uncertainty concerning the amount that must be paid, the payment's potential effect on a given transaction, and the added time and expense involved in negotiating with the recipients of the payment (Sutton, 1997). These factors have contributed to the finding by one analyst that investing in a relatively corrupt country, when compared with a less corrupt one, is equivalent to an additional 20\% tax on the investment (Wei in Kaufinann, 1997). Thus, in a very basic sense, corruption constitutes a source of uncertainty to investors as it imposes not only an additional cost on financial transactions, but also one that is variable and indeterminate in nature.

Corruption may also be construed as a source of economic risk and uncertainty to the extent that it constitutes a potential barrier to the free movement of trade and global capital flows through domestic markets. This effect derives from the co-existence of corruption with non-democratic and non-competitive political and economic regimes which are supported by a variety of regulative and legislative barriers restricting the accessibility of foreign capital to domestic markets. In fact, as previously revealed, it is these closed systems which generate the economic rents upon which corruption depends. Clearly, these forms of economic protectionism stand in direct contradiction to the demands of the global market for both unfettered and highly predictable access to domestic markets. In this respect, they are indicative of a critical source of economic risk to foreign investors. From this vantage point, it may be argued that corruption is problematic, not as a threat to national economic 
development and political stability as is commonly believed, but rather as an indication of non-competitive, and thus risky, market structures which threaten international investment. In this respect, within the context of international demands for the liberalization and democratization of developing economies, corruption stands as a proxy for a much broader series of economic issues and concerns.

The third element of the corruption-risk equation relates to the status of corruption as an indication of non-transparent and non-accountable market processes. This follows from the reality that the restrictive and noncompetitive market conditions typically associated with corrupt regimes not only constitute barriers to market access for global investors, but also create conditions in which there is a high degree of secrecy, and a corresponding lack of information, concerning political and economic activities. This follows from both the considerable authority, autonomy, and discretion with which individuals within corrupt regimes are able to execute their responsibilities, and the systematic absence of independent regulatory bodies designed to monitor these activities. Ultimately, the result of these conditions is a serious restriction on the flow of quality information to foreign investors, and thus, the introduction of a critical source of unpredictability into the market as investors are deprived of clear information on which to make investment decisions. This uncertainty inevitably undermines investor confidence, and thus, engenders market volatility. The importance of transparency in avoiding such a scenario is clearly captured by Kopits and Craig (1998) who argue that, "Fiscal transparency - defined as public openness in government institutions, fiscal policy intentions, public sector accounts, indicators, and forecasts - is fundamental to sound economic policy. Transparency allows the market to evaluate, and impose discipline on, government policy and increases the 
political risk of unsustainable policies" (Kopits and Craig, 1998: 13). Once again, corruption emerges from this discussion as a convenient surrogate for a broader set of socio-economic interests and concerns. What this suggests is that corruption is constituted as a source of economic risk within the discourse of transparency and accountability due largely to its association with an economic and political infrastructure which is noncommunicative, and thus, impervious to the demands of the international investment community. It is the obscurity of this institutional environment, rather than corruption in-and-of-itself, which is problematic from this global perspective.

Ultimately then, what we have is a dual issue. On the one hand, the global market demands free access to foreign markets. On the other hand, it also requires that this access be governed according to the recognized principles of the free market. To the extent that either of these conditions is not met, the expansion of the global market will be undermined. It is according to this specific context that corruption has emerged as a critical problem as it threatens both free market access, and the transparency and governability of this access once it has been achieved. These links between the liberalization of economic markets, the required transparency and governability of these markets, and the status of corruption as a threat to these twin pillars of the capitalist economy is clearly articulated by Almond and Syfert (1997) who identify liberalization and governability as two key trends within what they term the 'New Global Economy,'

One clear trend [in the New Global Economy] is the movement toward open markets and free trade. A consensus is emerging among economists that free trade benefits all who practice it, even though there remain many who do not. Free trade, its advocates relentlessly drum home, is best under all circumstances. Another recent trend - slower 
to develop, but potentially as powerful - concerns the darker, sometimes seamy underside of international business. As competition intensifies and margins shrink, governments and businessmen around the world are paying closer attention to the risks, costs, and consequences of bribery, graft, and other forms of corruption in international business. It is increasingly clear that these two trends are interrelated and interdependent. A truly open, free, and competitive world marketplace requires a trading system characterized by honesty, transparency, and fair dealing.

(Almond and Syfert, 1997: 391)

These same authors ultimately conclude from this characterization of the global economy that, "Corruption is fundamentally incompatible with international competitiveness; it distorts proper functioning of the market and drains confidence in a worldwide economic system dependent on tough, but fair competition" (Almond and Syfert, 1997: 403). Clearly what this suggests is that corruption has become largely defined and problematized in economic terms, and that this economic framework is both linked to the broader processes of economic globalization and exists independently of any substantive changes in absolute levels of corruption.

\section{Anti-corruption legislation}

Beyond general statements issued by international organizations, policy makers, and academics concerning the status of corruption as both a source of economic risk and a barrier to free trade, another important and informative component of the discourse on corruption relates to the debates surrounding 
proposed anti-corruption legislation, particularly within the context of the OECD. ${ }^{14}$ Framed explicitly as a "supply-side" approach to the corruption problem, the culmination of the OECD anti-corruption campaign came in December of 1997 with the signing of the OECD Paris Agreement. Consisting of commitments by member countries to establish national legislation criminalizing the payment of bribes by national corporations to foreign governments, this agreement represents one of the strongest unilateral indictments of transnational bribery, and is indicative of at least a symbolic commitment on the part of a number of different nations to combat the perceived corruption problem through the regulation of their own multinationals. The OECD Convention has since entered into force (Feb. 15, 1999) based on the submission of instruments of ratification by countries making up $60 \%$ of OECD exports. This included Canada, Japan, Germany, France, and the United States. As of Jan. 31, 2000, the required national legislation has been passed in twenty out of the thirty-four signatories.

The OECD Agreement is informative to the extent that it frames the need for anti-bribery legislation in terms of general concerns relating to globalization and the existence of corruption as a threat to the transparency, efficiency, and stability of the global market system, hence echoing the more general policy orientation of the organization. However, perhaps more revealing is the legislation's foundation in an effort on the part of the U.S. to multilateralize its own anti-corruption legislation: the Foreign Corrupt Practices Act (FCPA) (Klich, 1996; Roberts, 1989; Heidenheimer, 1996). Initially passed in 1977 as a reaction to a series of political and economic corruption scandals, the FCPA was the first legislation in the world to restrict the ability of domestic corporations to practice bribery in foreign nations. Since its passage, the FCPA has received a considerable amount of 
scrutiny given the contention by U.S. business interests that it undermines the competitive position of American corporations operating abroad. Specifically, it has been argued that American business interests are placed at a distinct disadvantage in relation to foreign corporations which are allowed to offer bribes in return for the procurement of lucrative contracts. Losses from this anti-competitiveness of the FCPA have been reported to be as high as $\$ 36$ billion. ${ }^{15}$

Based on this historical context, the U.S. efforts to introduce internationally binding restrictions against transnational bribery through the OECD may be viewed as part of an explicit strategy to level the economic playing field in response to the perceived restrictions of the FCPA (Mahaney, 1981; Roberts, 1989; Murphy, 1995; Klich, 1996; Muffler, 1995). In fact, a key provision of the 1988 Trade Act, which included various reforms to the FCPA, included a request that the President pursue the multilateralization of the FCPA within the context of the OECD (Roberts, 1989). This call for multilateralization has been echoed on a number of policy and academic fronts (Muffler, 1995).

Overall, there are a number of insights which follow from this relationship between the FCPA and the OECD Anti-Bribery Convention. First, corruption is approached primarily from the perspective of trade. In other words, the OECD initiative grew out of perceived inequalities in trade relations rather than any true concern with the implications of corruption for national development and economic efficiency - the most commonly cited motives for the fight against corruption. Despite the narrowness of this initial impetus, the rationale for the anti-corruption legislation has since been expanded to include more general concerns with economic efficiency and equal access to trade markets, hence both legitimating the Agreement as a policy that is good for all nations, and extending the economic approach to 
corruption.

Secondly, the OECD legislation highlights the role of subjective perceptions and opinions in the corruption debate. Almost all of the available evidence indicates that the FCPA does not constitute a significant threat to the competitiveness of U.S. corporations. First is the issue of actual economic effects. In this respect, a number of recent studies have found little evidence that the FCPA has had a major impact on U.S. exports and investments abroad (Almond and Syfert, 1997; Elliott, 1997, Klich, 1996). As Klich (1996) concludes, "Despite some recent reports, it is not at all clear that American companies are losing substantial investment opportunities because of the FCPA" (Klich: 141). Secondly, a number of authors have both identified ambiguities within the legislation which make it very difficult to enforce (Rosenthal, 1989; Meny, 1996), and noted the disinclination of the

U.S. government to pursue actual charges and convictions (Froot, 1998; Randall, 1997). ${ }^{16}$ Perhaps the best articulation of the problematic nature of the legislation is provided by Meny (1996) who argues that, "The effectiveness of this policy is nevertheless doubtful, owing to the many different possibilities of evasion and the difficulty of providing proof of these illegal practices. The official renumeration of 'brokers' or the use of local subcontracted companies to carry out the 'dirty job' are among the objectives sought without committing a statutory offence" (Meny, 1996: 317). Overall, the suggestion here is that anti-corruption legislation, like the corruption "problem" itself, is more perceived than real.

Finally, the OECD legislation is an expression of existing inequalities in economic power and influence - inequalities which may be seen to underlie the corruption discourse as a whole. Thus, while the fight against corruption is presented as a disinterested process designed to benefit the global economy 
as a whole, it is clear from this review that these initiatives are conceived and orchestrated by particular nations, in this case the United States, who are attempting to further their own economic and foreign policies under the legitimating guise of international legislation.

\section{Discussion: The economics of corruption and its control}

Taken as a whole, this discussion of the links between recent anti-corruption initiatives and global economic strategies suggests that the discourse of corruption must be understood within the context of economic globalization and the management of international capital flows. More specifically, this discourse emerges as part of a broader strategy of global economic, political, and social governance articulated through organizations such as the OECD, the World Bank, and the IMF. The links between corruption discourses and the forces of global economic governance have been revealed to take two primary forms. First, it is clear that, to a large extent, anti-corruption platforms have been inspired by the perceived threat posed by corrupt practices to international trade and investment flows. From this vantage point, international policies designed to restrict these practices may be interpreted as part of a broader effort to manage investment risk and ensure the stability and security of international trade. The existence of corruption as a transactional barrier, and hence, an investment threat is captured by Sutton (1997) who argues that, "The uncertainty that producers face regarding the amount they must pay and the payment's potential effect on a given transaction, the added time and expense producers face in negotiating with the recipients of the payment, and the

expenditure of an otherwise-unnecessary payment are all additional transaction costs which act as barriers to any investment" (Sutton, 1997: 
1439). Ultimately then, it becomes clear that corruption has emerged as a source of international concern due to its negative implications for international trade and investment (Almond and Syfert, 1997: 392) Once again, the well-being of developing nations emerges as a secondary concern within this global discourse.

Secondly, based on the wisdom that the elimination of non-competitive market conditions, reductions in the size of government, and the introduction of greater visibility and accountability into social and political institutions represent the optimal policy responses to corrupt practices, it may be argued that the discourse of corruption emerges as a central element in the legitimation of the Western agendas of liberalization and democratization policies which, in reality, have been revealed to increase corrupt behaviours and social inequalities. The explicit link between anti-corruption initiatives and Western political interests is revealed in the recent decision by organizations such as the World Bank and the IMF to make their loans contingent upon the reduction of corruption levels - usually through the fulfillment of directives such as privatization and market liberalization. This corruption-contingent status of loans is explicitly disclosed in a 1997 World Bank press release which makes reference to the new IMF policy,

The International Monetary Fund, in new guidelines released in August, has warned its member countries that financial assistance may be withheld or suspended if government corruption is preventing their economies from moving out of trouble. The guidelines specifically mention as causes for corruption the diversion of public funds through misappropriation, involvement of public officials in tax or customs fraud, the misuse of foreign exchange reserves, and abuses of power by bank supervisors, as well as corrupt practices in regulating foreign direct investment.

(World Bank, 1997c: 1) 
This strategy is particularly significant within the context of the Asian economic crisis where bailout packages, sponsored by the U.S. dominated IMF, were made contingent upon the satisfactory implementation of economic reforms which, in the long run, may be seen to favour Western business and political interests. Given the identification of corruption as a key factor in the collapse of various Asian economies, transparency, accountability, and democratization emerged as important elements of IMF-sponsored reform efforts in countries such as Thailand, Indonesia, and Korea (IMF, 1997). This emphasis upon transparency and accountability in the surveillance efforts of the IMF following the Asian crisis are clearly revealed in a recent IMF report,

The IMF's work on surveillance issues intensified following the outbreak and spread of the financial crisis to other Asian economies and the subsequent pressures on other emerging market economies. Surveillance was also intensified in recognition that promoting good governance, making budgets more transparent, improving data collection and disclosure, and strengthening financial sectors are increasingly important if countries are to establish and maintain private sector confidence and lay the groundwork for sustained growth.

(IMF, 1998: 2)

Ultimately then, it appears that anti-corruption strategies once again emerge as valuable foils for the promotion of specific strategies of democratization, liberalization, and economic reform (trade and investment liberalization) which, in turn, are supportive of powerful economic and political interests. In the Asian case, anti-corruption initiatives have provided a key opportunity for the penetration of U.S. business interests into the once lucrative Asian market, 
primarily through the growing influence and mandates of the World Bank and IMF and their ability to enforce macroeconomic reform through loan conditionalities. The intersection of these underlying economic and political interests is clearly expressed by Jomo (1998) in reference to the Korean context, "Almost in tandem with financial liberalization, IMF intervention is generally recognized to undermine and limit national economic sovereignty. Particularly damning is the clear abuse of imposed IMF conditionalities in the Korean aid package to resolve outstanding bilateral issues in favour of the US and Japanese interests. Legislation and other new regulation enabling greater foreign ownership of as well as increased market access to the Korean economy - which have little to do with the crisis or its immediate causes have been forced upon the Korean government" (Jomo, 1998: 21).

\section{Conclusion}

In summary, it appears from the above analysis that the discourse of corruption has emerged as a crucial medium for the articulation and promotion of global economic and political strategies designed to increase the flow of global capital through both the management of potential risks, of which corruption is one, and the reduction of trade barriers. Given the links between these strategies and the broader processes of democratization and liberalization, it becomes apparent that anti-corruption strategies must be understood within the context of global relations of ruling and the efforts made by particular nations to govern the world economy in the interest of promoting specific national economic and political objectives. In this respect, the discourse of corruption may be seen to contribute to the production, re-production, and legitimation of an ethic of globalization which itself represents an important form of domination and control. This 
very point is made by Silbey (1997) who relates globalization to what she terms 'postmodern colonialism,' "I regard globalization as a form of postmodern colonialism where the worldwide distribution and consumption of cultural products removed from the contexts of their production and interpretation is organized through legal devices to constitute a form of domination" (219). As she goes on to argue, the principle of the free market is essential to this vision of globalization, "Globalization, or what I am calling postmodern colonialism, is an achievement of advanced capitalism and technological innovation seeking a world free from restraints on the opportunity to invent and invest" (219). The extent to which this vision of globalization - as a form of both liberalization and control - is simultaneously endorsed and promoted by organizations such as the OECD, the IMF, the World Bank, and the World Trade Organization is clearly revealed in a 1997 OECD policy statement on the "New Global Age,"

In the rapidly changing and globalizing world economy, there will be an even greater need for international co-operation so as to realize a "New Global Age," and the role of the multilateral system will become even more important. There is a growing internationalization of many policy issues, which were previously more domestic in nature. And countries are increasingly confronted with a common set of policy problems, on which common solutions through identification of best practices and multilateral surveillance can be effective. In this context, the whole range of international institutions - from the UN system and the WTO, to the IMF and the multilateral development banks, and to the many regional groupings - is now working to develop policies that promote economic prosperity, political security (including through enhanced economic interdependence) and sustainable development - policies that would help realize a "New Global Age."

(OECD, 1997: 36) 
Overall, what this discussion suggests is that the issue of corruption must be approached through a critical framework which is cognizant of the broader contexts and conditions according to which the corruption debate has been fashioned, and the interests which it acts to support. The development of such a critical position bears consequences not only for the treatment of corruption as a social issue, but also for more general questions concerning globalization and its implications for governance, crime, and social control. Specifically, there is a growing need for criminology to come to terms with the existence of globalization as a new conceptual and empirical space which is being used to promote and legitimate a fundamental re-thinking of the social order as it is conceived on a global scale. This speaks to the observation by Tita that, "It is a fact that globalization has created a new political and economic space, against which the existing established powers have not yet perfected an adequate response" (Tita, 1998: 48). Based on the foregoing analysis, it appears that this order is increasingly being articulated according to an exclusively economic logic through a series of organizational and institutional intermediaries which transcend the traditional boundaries of the nation-state. ${ }^{17}$ In this respect, the problematization of corruption is significant to the extent that it provides a critical perspective on this emerging order, and thus, a point from which criminology, and social theory more generally, may begin to assess the nature and significance of globalization's new space. 


\section{Notes}

1. According to one estimate, corruption has existed worldwide in multiple forms from approximately 3000 B.C. to the present day (Noonan, 1984 in Sutton, 1997).

2. Both the IMF and World Bank have recently introduced reforms to their lending practices making the provision of funds conditional upon the successful implementation of a variety of macroeconomic and anti-corruption reforms. This use of conditionalities to effect desired structural changes in domestic economies has been met with severe criticism from a variety of national leaders as yet another form of Western imperialism.

3. The most common definition of corruption applied within the policy and academic literature is, "the abuse of public office for private gain" (World Bank, 1997a: 8) with this abuse understood primarily in terms of the offering and acceptance of bribes by public officials. According to the World Bank, "Public office is abused for private gain when an official accepts, solicits, or extorts a bribe. It is also abused when private agents actively offer bribes to circumvent public policies and processes for competitive advantage" (World Bank, 1997a: 8).

4. Of the leading researchers on corruption, two are members of international development organizations. This includes Paulo Mauro, an economist in the IMF's European I Department, and Daniel Kaufmann, a lead economist in the World Bank's Development Research Group.

5. Both competitive pressures operating on the initial agreement, and the possible requirement of future payments make corruption a variable economic cost faced by investors.

6. It must be noted that the evidence for this increase is primarily anecdotal and subjective in nature. Typically, it is based on corruption indexes published by organizations such as Transparency International which ask respondents, primarily from the field of business, to provide ratings of the perceived level of corruption within a number of different countries. Critics have responded to this methodology by noting that it is virtually impossible to establish accurate, objective measures of corruption (RoseAckerman, 1997; Meny, 1996). Thus, Susan Rose-Ackerman (1997) has argued that, "Reliable data on the magnitude of corruption across countries does not exist and probably cannot exist in principle" (Rose-Ackerman, 1997: 31). Meny (1996) comes to a similar conclusion, "... the real or assumed extent of corruption is as much a matter of perception and feeling as a mathematical measurement of the phenomenon" (Meny, 1996: 310). Nevertheless, even the recognition of these data limitations has not prevented some key commentators from claiming significant increases in corruption levels, "However incomplete, data from developing and postsocialist countries confirm the widespread impression that corrupt practices are increasing" (Leiken, 1997: 61).

7. Once again, methodological barriers to the accurate measurement of corruption levels draws into serious question the validity of these types of studies - all of which rely on subjective corruption indices provided by organizations such as Transparency International.

8. Additional sources of economic rents include: trade restrictions, government subsidies, price controls, multiple exchange rate systems and foreign exchange allocation schemes, and low wages in civil service.

9. Indices of this economic integration include the greater contribution of non-OECD countries to world Gross Domestic Product (GDP), and significant increases in the ratio of trade to GDP and higher levels of Foreign Direct Investment in developing economies (OECD, 1997: 15-16).

10. As the recent economic crises in Asia, Latin America, and the Soviet Union have revealed, these developments have not been without their costs. In each of these cases, advancements in economic integration figured prominently in the economic collapse as domestic economies became increasingly dependent upon foreign investments, and thus, subject to the vicissitudes of the market and the possibility of capital flight.

11. World Bank officials suggest that, there are two forces driving investor interest in developing countries: the search for higher returns, and opportunities for risk diversification (World Bank, 1997d). The demand for new investment opportunities is particularly acute given the growing number and strength of institutional investors (i.e. mutual funds, and pension funds) who are in search of diversified investment portfolios.

12. World Bank officials suggest that investor confidence is linked to three main considerations, "Investors are concerned with the unreliability of emerging markets in three main areas: market infrastructure (where the consequences include high transaction costs, frequent delays in settlement, and outright failed trades); protection of property rights, in particular those of minority shareholders; and disclosure of market and company information and control of abusive market practices" (World Bank, 1997d: 6). 
13. This type of effect figured prominently in the recent Asian financial crisis.

14. Similar anti-bribery initiatives have been undertaken by the Organization of American States (OAS) with its Inter-American Convention Against Corruption, the United Nations, the European Union, and the World Trade Organization (WTO).

15. This figure is based on a 1995 classified CIA report, and represents an estimate of the value of the contracts lost during that year by U.S. companies to foreign competitors who were not bound by anti-bribery legislation. In his comments on these reported losses, Klich notes that they are largely based on anecdotal evidence, and thus, do not constitute conclusive evidence of the deleterious effects of the FCPA. This leads him to the conclusion that, "Overall, studies of the FCPA's impact on the competitiveness of U.S. companies has been inconclusive, frequently reaching inconsistent conclusions. Given such discrepancies, one cannot unequivocally conclude that the loss of business because of the FCPA is material and one cannot assess just how significant that loss is in the grand scale of U.S. investment overseas" (Klich, 1996: 141).

16. According to Randall (1997), between the period of 1977-1988 the Department of Justice initiated only 20 anti-bribery cases under the FCPA, while the Securities Commission launched only three.

17. Here an interesting parallel is revealed with the work of theorists in the governmentality tradition such as Rose and Miller (1992). Among the various transformations in social control noted by these authors in what they refer to as neo-liberal society, the most significant from our point of view is the shift away from the State as a primary site of governance and control towards a series of intermediary institutions, as well as the growing articulation of social control according to a purely economic and actuarial logic. We believe this to be entirely consistent with both the growing influence of organizations such as the World Bank, the IMF, and the OECD in the global social order, and the organization of this order in conjunction with the principles of economic liberalization and the minimization of financial risk and uncertainty. The governmentality tradition thus emerges as a theoretical complement to our primarily substantive analysis. 


\section{References}

Ades, Alberto and Rafael Di Tella, "The Causes and Consequences of Corruption: A Review of Recent Empirical Contributions," IDS Bulletin 1996, 27, 2, 6-11.

Almond, Michael A. and Scott D. Syfert, "Beyond Compliance: Corruption, Corporate Responsibility and Ethical Standards in the New Global Economy," North Carolina Journal of International Law and Commercial Regulation 1997, 22, 389-447.

Bray, John, "Bribe Wars: International agencies are ready to escalate the fight against corruption," Accountancy 1998, March, 30-31.

Doig, Alan, "Dealing with Corruption: The Next Steps," Crime, Law, and Social Change 1998, 29: 99-112.

Elliott, Kimberly Ann, "Corruption as an International Policy Problem: Overview and Recommendations," in Kimberly Ann Elliott (ed.), Corruption and the Global Economy, pp. 175-233, (Washington, DC: Institute For International Economics, 1997).

Flannery, Rachel, "The State in Africa: Implications for Democratic Reform," Crime, Law, and Social Change 1998, 29: 179-196.

Froot, Steven, "US Anti-Corruption Philosophy Gains Ground," The China Business Review 1998, Jan-Feb., 26-27.

Gardiner, John A., "Defining Corruption,' Corruption and Reform 1993, 7, 111-124.

Gibbons, Kenneth M., "Toward an Attitudinal Definition of Corruption," in Arnold J. Heidenheimer, Michael Johnston and Victor T. LeVine (eds.), Political Corruption: A Handbook, pp. 165-172, (London: Transaction Publishers, 1989).

Glynn, Patrick, Stephen J. Kobrin and Moises Naim, "The Globalization of Corruption," in Kimberly Ann Elliott (ed.), Corruption and the Global Economy, pp. 7-27, (Washington, DC: Institute for International Economics, 1997).

Goudie, A.W. and David Stasavage, "A Framework for the Analysis of Corruption," Crime, Law and Social Change 1998, 29, 113-159.

Gray, Cheryl W. and Daniel Kaufmann, "Corruption and Development,' Finance and Development 1998, 35, 1, 7-10.

Hampton, Mark P., "Where Currents Meet: The Offshore Interface Between Corruption,

Offshore Finance Centres, and Economic Development," IDS Bulletin 1996, 27, 2, 78-87.

Hariss-White, Barbara and Gordon White, "Corruption, Liberalization and Democracy: Editorial Introduction,” IDS Bulletin 1996, 27, 2, 1-5.

Heindenheimer, Arnold J., "Perspectives on the Perception of Corruption," in Arnold J. Heidenheimer, Michael Johnston and Victor T. LeVine (eds.), Political Corruption: A Handbook, pp. 149-164, (London: Transaction Publishers, 1989).

International Monetary Fund, World Economic Outlook, 1997.

International Monetary Fund, Annual Report, 1998.

Johnston, Michael, "The Search for Definitions: The Vitality of Politics and the Issue of Corruption," International Social Science Journal 1996, 48, 3, 321-335.

Jomo, K.S., "Introduction: Financial Governance, Liberalization, and Crises in East Asia," in K.S. Jomo (ed.), Tigers in Trouble: Financial Governance, Liberalization, and Crises in East Asia, (New York: Zed Books, 1998).

Kaufmann, Daniel, “Corruption: The Facts,” Foreign Policy 1997, 107, 114-130.

Klich, Agnieszka, "Bribery in Economies in Transition: The Foreign Corrupt Practices Act," Stanford Journal of International Law 1996, 32, 121-147.

Klitgaard, Robert, Controlling Corruption, (Berkeley: University of California Press, 1988).

Kong, Tat Yan, "Corruption and its Institutional Foundations: The Experience of South Korea," IDS Bulletin 1996, 27, 2, 48-55.

Kopits, George and Jon Craig, Transparency in Government Operations, International Monetary Fund Occasional Paper No. 158, (Washington, DC: International Monetary Fund, 1998)

Leiken, Robert S., "Controlling the Global Corruption Epidemic," Foreign Policy 1997, Winter, 55-73.

LeVine, Victor T., "Transnational Aspects of Political Corruption,” in Arnold J. Heidenheimer, Michael Johnston and Victor T. LeVine (eds.), Political Corruption: A Handbook, pp. 685700, (London: Transaction Publishers, 1989).

Mahaney, Mary Claire, "The Foreign Corrupt Practices Act: Curse or Cure?" American Business Law Journal 1981, 19, 73-86.

Mauro, Paolo, Why Worry About Corruption? International Monetary Fund Economic Issues Series No. 6: 1997.

Mauro, Paolo, "Corruption: Causes, Consequences, and Agenda for Further Research," Finance and Development 1998, 35, 1, 11-14.

Meny, Yves, “ 'Fin de Siecle' Corruption: Change, Crisis, and Shifting Values," International Social Science Journal 1996, 48, 3, 309-320. 
Muffler, Stephen, "Proposing a Treaty on the Prevention of International Corrupt Payments: Closing the Foreign Corrupt Practices Act Is Not the Answer," ILSA Journal of International and Comparative Law 1995, Spring, 3-39.

Murphy, Mark J., "International Bribery: An Example of an Unfair Trade Practice?," Brooklyn Journal of International Law 1995, 21, 2, 385-424.

Organization for Economic Co-operation and Development, OECD Working Papers: OECD Symposium on Corruption and Good Governance, Vol. iv, No. 78, (Paris: OECD, 1996).

Organization for Economic Co-operation and Development, Towards New Global Age: Challenges and Opportunities, (Paris: OECD, 1997).

Organization for Economic Co-operation and Development, Draft Principles of Corporate Governance, (Paris: OECD, 1999).

Randall, Lisa Harriman, "Multilateralization of the Foreign Corrupt Practices Act," Minnesota Journal of Global Trade 1997, 6, 657-684.

Roberts, Judith L., "Revision of the Foreign Corrupt Practices Act by the 1988 Omnibus Trade Bill: Will it Reduce the Compliance Burdens and Anticompetitive Impact?," Brigham Young University Law Review 1989, 2, 491-506.

Rodrick, Dani and James E. Rauch, "Comments" in Kimberly Ann Elliott, (ed.), Corruption and the Global Economy, pp. 109-116. (Washington, DC: Institute for International Economics, 1997).

Rose, Nikolas and Miller, Peter, "Political Power Beyond the State: Problematics of Government," British Journal of Sociology 1992, 43, 2, 173-205.

Rose-Ackerman, Susan, 'The Political Economy of Corruption," in Kimberly Ann Elliott, (ed.), Corruption and the Global Economy, pp. 31-60. (Washington, DC: Institute for International Economics, 1997).

Rosenthal, Michael, "An American Attempt to Control International Corruption," in Arnold J. Heidenheimer, Michael Johnston and Victor T. LeVine (eds.), Political Corruption: A Handbook, pp. 701-718, (London: Transaction Publishers, 1989).

Silbey, Susan S., “' 'Let Them Eat Cake': Globalization, Postmodern Colonialism, and the Possibilities of Justice," Law and Society Review 1997, 31, 2, 207-235.

Sutton, Robert H., "Controlling Corruption Through Collective Means: Advocating the InterAmerican Convention Against Corruption," Fordham International Law Journal 1997, 20, 1427-1478.

Tarkowski, Jacek, "Old and New Patterns of Corruption in Poland and the USSR," Telos 1989, $80,51-62$

Tita, Alberto, "Globalization: A New Political and Economic Space Requiring Supranational Governance," Journal of World Trade 1998, 32, 3, 47-56.

Transparency International, Transparency International Canada Newsletter 1998, 2, 2, April, $1-4$.

White, Gordon, "Corruption and Market Reform in China," IDS Bulletin 1996, 27, 2, 40-47.

World Bank, Helping Countries Combat Corruption: The Role of the World Bank, www.worldbank.org. 1997a.

World Bank, "Reducing Corruption," World Bank Policy and Research Bulletin 1997b, www.worldbank.org. 8, 3, 1-4.

World Bank, World Bank, IMF Escalate War Against Corruption: Latest Ranking by Transparency International 1997c, www.worldbank.org.

World Bank, Private Capital Flows to Developing Countries: The Road to Financial Integration, (London: Oxford University Press, 1997d).

Zedalis, Rex J., "How Does the New OECD Convention on Bribery Stack Up Against the Foreign Corrupt Practices Act?," Journal of World Trade 1998, 32, 3, 167-184. 